\title{
Poem
}

\section{Star of Braintree}

I think I saw my sister

Soft-skinned star of Braintree

In the image of my nan, passing.

Youth following four years behind

And age ahead, sixty years senior

Their faces, same

Move slow in single steps, sister

Don't seek your mother's tears

Or her image of being, broken.

The fate of females before you:

Mum's misery, born of her mum's madness

Will end

Join me at her bed, sister

Summon her Spring in yours

And the image of your dad, a son.

The opiate drips that outline her

And enduring moors of Milngavie

Are the same

Ease my fear, nurse sister

Become her, not your mum

Or the image of hers, passed out.

Slow mid-life Matalan sadness

Or late senility, after decades active

Choose

Awake, sweet silver-eyed sister

From diamorphine dreams

And images of war-roused lovers.

Speed for the skyline breeze unforced

To meet her falling dying mind

And hold her

Soft-skinned star of Braintree

Let her hold you. 